\title{
The Effect of Financial Performance and Sales Growth on Dividend Policy with Firm Size as Moderating Variable in Automotive Sub-Sector Manufacturing Companies Listed on the IDX in 2016-2019
}

\author{
Taufiqurrahman $^{1}$, Erlina ${ }^{1}$, Khaira Amalia Fachrudin ${ }^{1}$ \\ ${ }^{1}$ Department of Accounting, Faculty of Economics and Business at Universitas Sumatera Utara, Indonesia
}

Corresponding Author: Taufiqurrahman

\begin{abstract}
This study aims to determine the effect of financial performance and sales growth on dividend policy with firm size as a moderating variable in automotive sub-sector manufacturing companies listed on the Indonesia Stock Exchange (IDX) in 2016-2019.

This research was conducted based on information obtained on the Indonesia Stock Exchange. This research uses the purposive sampling method. The population in this study is the automotive sub-sector manufacturing companies listed on the Indonesia Stock Exchange from 2016 to 2019, with a sample of 13 companies. The analysis technique used is by using software views.

The results of this study indicate that Liquidity (CR) and Leverage (DER) have a significant effect on dividend policy while the variables Profitability (ROA), Leverage (DER), Activity (TATO), Growth, and Sales Growth have no significant effect on Dividend Policy in Automotive Sub-Sector Manufacturing Companies Listed on the IDX. The results of this study also show that Firm size can moderate Profitability (ROA), Leverage (DER), and Activity (TATO) on Dividend Policy. However, Firm size cannot moderate Liquidity (CR), Growth, and Sales Growth on Dividend Policy in the sub automotive sector listed on the Indonesia Stock Exchange.
\end{abstract}

Keywords: Liquidity (CR), Profitability (ROA), Leverage (DER), Activity (TATO), Growth,
Sales Growth, Dividend Policy (DPR), Firm Size

\section{INTRODUCTION}

The dividend policy is one of the crucial decisions of the company and is an integral part of the company's spending decisions. Dividend policy is one of the indicators in the company for the welfare of its investors (Fitriana et al., 2018). Baker \& Powell (2012) state that dividend policy signals investors regarding future cash flows. Each company must have a different policy that will influence the manager's decision to distribute the benefits to shareholders in dividends or hold them in retained earnings. Therefore, dividend distribution is a fascinating phenomenon to study because management will undoubtedly face difficulties in how to make decisions in determining the right dividend policy.

Dividend distribution is a complicated issue in the company due to differences in interests between shareholders and company management. Shareholders want dividends to be paid as much as possible, while the company's management wants company profits to be retained to reinvest. Investors assess that the decision to hold earnings will cause concern for shareholders about the use of profits and only provide benefits to managers. It will 
trigger a conflict between shareholders and company managers called agency conflict (Jensen \& Meckling, 1976). The reason for the importance of dividend policy is because retained earnings are the largest and most important source of internal funds for company growth. The distribution of dividends will reduce the company's cash to decrease the available funds to finance operations and investment activities. It means that dividend policy is essential for the company because it affects internal sources of funds, which indicates the level of liquidity of a company is paying its obligations.

In order to avoid agency conflicts, it is necessary to supervise in aligning the interests of the management with the shareholders, one of which is the distribution of cash dividends, namely the distribution of profits in the form of cash (Dividend Cash). Dividend distribution that increases each period will be difficult for the company to achieve because the profits obtained by the company do not always increase but fluctuate. The decline in dividends can be influenced by various aspects, such as economic decline and social-cultural.

In this study, the object of research is the automotive subsector manufacturing company. The automotive sector in Indonesia is facing challenges throughout 2019 caused by the coronavirus-19 pandemic. It is reflected in the slowdown in vehicle sales. Referring to the motor vehicle industry (Gaikindo), car sales and manufacturers' dealers fell $16.4 \%$ for the January-May 2019 period. Gaikindo did not deny that this pandemic could hamper the pace of the national automotive industry for a long time. So companies are required to be able to find strategies to be able to survive during competition during the COVID-19 pandemic.

Panin Sekuritas analysis Nico Laurens said that the stagnant national economic growth of 5\% plus lower commodity prices affected the demand for cars in the community. Not to mention, the quality of public transportation in several major cities in the country has improved significantly. It slowly encourages people to use public transportation, which is relatively affordable, and the proliferation of online transportation, which has begun to change people's consumption patterns towards private vehicles. Sucor Sekuritas analyst Edward Lowis added that the slowdown in car sales was also exacerbated by the massive entry of international automotive manufacturers in recent years. This condition results in Indonesia's existing production capacity being underutilized when the economy is stagnant. It is one of the causes of a decrease in the dividend income of an automotive company. The following is data on the average Dividend Payout Ratio (DPR) and Current Ratio (CR) in automotive sub-sector manufacturing companies listed on the Indonesia Stock Exchange (IDX) in 2016-2019.

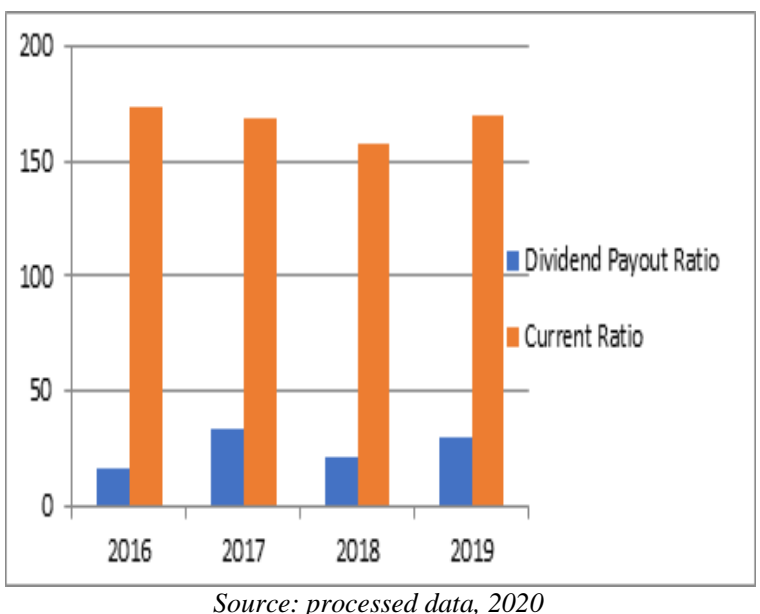

Figure 1. Average DPR and CR of Manufacturing Companies in the Automotive Sub-Sector 2016-2019

Figure 1 shows the average dividend distribution received by shareholders. In 2016 the average Dividend Payout Ratio was 16.61 then, experienced a significant increase to 32.92 in 2017. There was a significant decrease in 2018 to 20.79 . In 2019 it increased again to 30.14. This fluctuation phenomenon is caused by several factors, one of which is liquidity. When liquidity increases, the dividends distributed will be higher (Lestari et al., 2016). It is also supported by the research of Pramana \& Sukarta (2015). According to 
signaling theory, information about the company's current ratio is very important for making investment decisions because the higher the current ratio, the higher the company's ability to pay the promised dividends (Permatasari, 2018). However, based on the research data in Figure 1, it can be seen that in 2017 there was an increase in the average DPR from 16.61 to 32.92 but, in the same year, the Current Ratio decreased from 173.11 to 168.89 . Because of this theoretical gap, the researcher is interested in testing this research again.

According to Hani (2015), liquidity is the ability of a company to meet all financial obligations that can be immediately disbursed or that are due. Precisely, liquidity reflects the availability of funds owned by the company to meet all maturing debts. Companies with a high level of liquidity usually have a better chance of getting various supports from many parties, such as financial institutions, creditors, and suppliers. Liquidity has a direct relationship with the dividend policy, where the greater the liquidity of a company, the greater the company's ability to pay dividends (Sartono, 2001).

The research results by Nugraheni \& Mertha (2019) stated that liquidity had a positive and significant effect on dividend policy. The results of this study are in line with Andriani (2016) and Masril (2017). In contrast to the results of research by Nur (2018), which states that liquidity does not affect dividend policy. The results of this study are supported by the research of Sulaiman \& Sumani (2016) and Arilaha (2009).

Profitability is an indicator used to measure the effectiveness of overall management, which is indicated by the size of the level of profit obtained with sales and investment. The better the profitability ratio, the better it describes its high profitability (Fahmi, 2015). The increase in company profits will also increase the distribution of dividends to shareholders. It means that profitability has a positive influence on dividend policy.
The results of Nur's research (2018) state that profitability has a positive and significant effect on dividend policy. These results are in line with the research of Andriani (2016) and Arilaha (2009). This study's results are contrary to Sulaiman \& Sumani's (2016) research, which obtained that profitability does not significantly affect dividend policy. This result is supported by the research of Susanty et al. (2017).

According to Syamsudin (2013), leverage is the company's ability to meet its financial obligations both in the short and long term or measure how far the company is financed by debt. According to Munawir (2010), leverage is the company's ability to meet all of its financial obligations if the company is liquidated, both short-term and long-term financial obligations. The use of too high debt will harm the company because the company will fall into extreme debt. Namely, the company is trapped in a high level of debt, and it is difficult to release the debt burden. It is generally essential for a creditor because it will show the company's financial position. Thus, if a company has a larger debt ratio, it will impact lower dividends because the higher the debt paid, the lower the profit (Arilaha, 2009).

According to Gupta's research (2018), it is revealed that debt has a negative effect on dividend policy. The higher the proportion of debt or the increasing debt used in the capital structure, the greater the obligation. In contrast to Kuswanta's research (2016), leverage has a significant influence on dividend policy. These results are in line with the research of Kautsar (2014).

Sitanggang (2014) Total Asset Turnover is a ratio that measures how all assets owned by the company are operationalized to support the company's sales. The activity ratio is a ratio that measures how effective the company is in utilizing all the resources available to it. These activity ratios involve comparisons between the level of sales and investment in 
various types of assets. Low assets at a certain level of sales will result in more significant excess funds embedded in these assets. The excess funds would be better if invested in other more productive assets. High asset turnover will reflect the company's financial performance. That way, the higher the company's asset turnover means the higher the company's ability to distribute dividends, and vice versa (Amalia, 2013). The research results by Susanty et al. (2017) show that activities proxied using TATO significantly affect dividend policy. It is supported by research by Magdalena et al. (2018).

Growth impacts the company's flow of funds from operational changes caused by growth or decline in business volume. The issuer's decision to grow will affect the availability of funds for the issuer. When a company decides to grow, the issuer must raise funds to finance its growth needs. The company's growth is highly expected by the company's internal and external parties because, from the investor's point of view, the company's growth is a sign that the company has profitable prospects (Priyo, 2013). According to Puspitaningtyas (2019), the growth rate reflects its ability to maintain its economic position. The company's growth is expected to give a positive signal of investment opportunities. The research results of Purba et al. (2020) stated that growth had a significant negative effect on dividend policy.

Sales growth is an essential indicator of market acceptance of the company's products and or services, where the income generated from sales can be used to measure the level of sales growth (Swastha and Handoko, 2011). Sales growth reflects the manifestation of past investment success and can be used to predict future growth. Sales growth is also an indicator of the demand and competitiveness of companies in an industry. The growth rate of a company will affect the ability to maintain profits in financing opportunities in the future (Barton et al., 1989). Sales growth can also affect dividend policy. The amount of sales growth is certainly needed for the company's operational activities to make a profit. If the company focuses on the company's sales growth, it will increase costs and, of course, will make dividends paid low or not at all (Hadiatmo, 2013). Sales growth will have consequences for increasing investment in assets and ultimately require considerable funds. It is what makes profits that will be used to buy assets so that the dividends distributed will be smaller.

The results of Kautsar's research (2014) say that sales growth has a significant effect on dividend policy. In contrast to Darmayanti and Mustanda's (2016) research results, sales growth has no significant effect on dividend policy.

In Widiastari \& Yasa's (2018) research, it is stated that firm size is a scale where the company's size can be classified as measured by total assets, total sales, share value, etc. Windy \& Wendy (2018) explain that the company's size is seen from the business field that is being operated. Firm size can be determined based on total sales, total assets, average sales level. Firm size can be used to represent the company's financial characteristics. Large companies that are well stabilized will find it easier to obtain capital in the capital market than small companies. Because the ease of access means large companies have great flexibility. The size of the company also determines the level of investor confidence. The bigger the company, the more recognized by the public, which means it is easier to get information that will increase its value. Dewi (2008), in her research, states that the size of the company has a positive and significant effect on dividend policy, meaning that the larger the size of the company, the higher the distribution of dividends. It is because distributing high dividends will maintain a reputation among investors. Meanwhile, small companies will allocate profits to retained earnings to increase company assets so that companies tend to distribute low dividends. 
Nursandari (2015) states that firm size can moderate the relationship between ROE and liquidity with dividend policy. The results of Nur's research (2018) say that firm size can moderate the effect of profitability on dividend policy. Mahdzan et al. (2016) found that firm size had a significant effect on dividend policy. This result is in line with Ahmad and Wardani (2014). This result is not in line with Aurangzeb and Dilawer (2012), who found that firm size does not affect dividend policy. This result is in line with Darmayanti and Mustanda (2016).

\section{Framework}

Following the description of the background of the problem, literature review, and previous research, a conceptual research framework is prepared as follows:

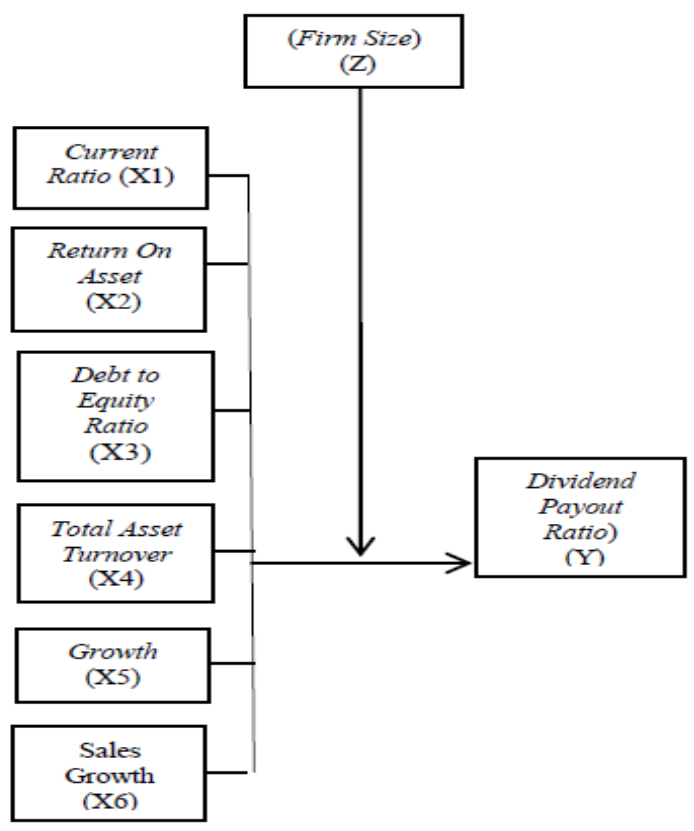

Figure 2: Conceptual Framework

H1: Liquidity has a significant effect on Dividend Policy.

H2: Profitability has a significant effect on Dividend Policy.

H3: Leverage has a significant effect on Dividend Policy.

H4: Activity Ratio has a significant effect on Dividend Policy.

H5: Growth has a significant effect on Dividend Policy.
H6: Sales Growth has a significant effect on Dividend Policy.

H7: Firm size can moderate the effect of Liquidity on Dividend Policy.

H8: Firm size can moderate the effect of Profitability on Dividend Policy.

H9: Firm size can moderate the influence of Leverage on Dividend Policy.

H10: Firm size can moderate the effect of Activity Ratio on Dividend Policy.

H11: Firm size can moderate the effect of Growth on Dividend Policy.

H12: Firm size can moderate the effect of Sales Growth on Dividend Policy.

\section{RESEARCH METHODS}

This type of research is causal associative research to determine the effect of Financial Performance and Sales Growth as an independent variable on the dependent variable, namely Dividend Policy with Firm size as the moderating variable. The causal associative study analyzes the relationship between one variable and another to know how one variable affects other variables (Erlina, 2011). The data analysis method used in this study is a statistical analysis method using Eviews10 software. Data analysis performs by testing standard assumptions and testing hypotheses.

The population used in this study is 12 automotive sub-sector manufacturing companies listed on the Indonesia Stock Exchange during the 2016-2019 period. The sampling technique used in this study was purposive sampling.

\section{RESULT AND DISCUSSION Normality Test}

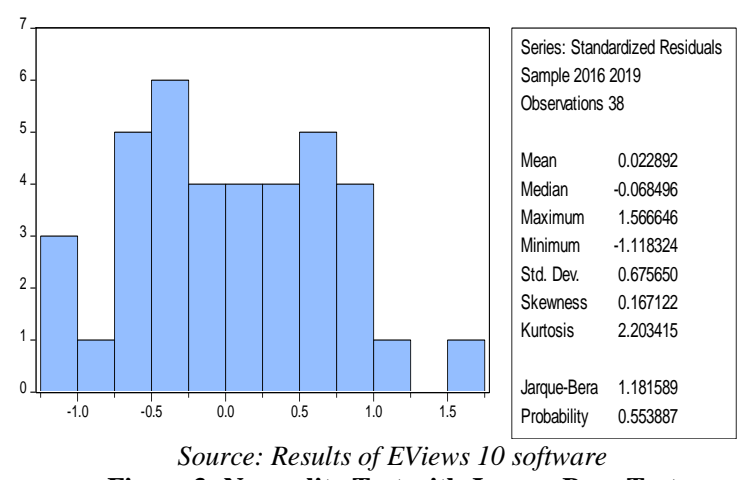

Figure 3: Normality Test with Jarque-Bera Test 
Based on the table above, it can be concluded that the probability value of 0.553887 is larger than 0.05 so that the data is normally distributed. So that further testing can be carried out.

\section{Panel Data Regression Model Estimation Common Effect Model Test}

Table 1. Common Effect Model Test Results

\begin{tabular}{l} 
Table 1. Common Effect Model Test Results \\
\begin{tabular}{|l|l|l|}
\hline Variables & Coefficient & Probability \\
\hline Constanta & $-0,903213$ & 0,107 \\
\hline X1 & $-0,207383$ & 0,0337 \\
\hline X2 & $-214,9638$ & 0,1985 \\
\hline X3 & $-0,310153$ & 0,0136 \\
\hline X4 & 215,2728 & 0,1977 \\
\hline X5 & 0,015466 & 0,5487 \\
\hline X6 & 1,086257 & 0,3494 \\
\hline
\end{tabular} \\
\hline
\end{tabular}

\section{Fixed Effect Model (FEM) Test}

\begin{tabular}{|l|l|l|}
\multicolumn{4}{|c|}{ Table 2. Fixed Effect Model Test Result } \\
\hline Variable & Coefficient & Probability \\
\hline Constanta & $-1,532145$ & 0,3821 \\
\hline X1 & $-0,329411$ & 0,1077 \\
\hline X2 & $-40,54584$ & 0,8017 \\
\hline X3 & $-0,04725$ & 0,9364 \\
\hline X4 & 41,55234 & 0,797 \\
\hline X5 & 0,022786 & 0,4291 \\
\hline X6 & 0,542502 & 0,6333 \\
\hline
\end{tabular}

\section{Random Effect Model Test}

Table 3. Random Effect Model Test Result

\begin{tabular}{|l|l|l|}
\hline Variable & Coefficient & Probability \\
\hline Constanta & $-0,981318$ & 0,123 \\
\hline $\mathrm{X} 1$ & $-0,248918$ & 0,0171 \\
\hline $\mathrm{X} 2$ & $-129,6168$ & 0,3543 \\
\hline $\mathrm{X} 3$ & $-0,330474$ & 0,0243 \\
\hline $\mathrm{X} 4$ & 130,1334 & 0,3522 \\
\hline $\mathrm{X} 5$ & 0,019122 & 0,3889 \\
\hline $\mathrm{X} 6$ & 0,940831 & 0,3141 \\
\hline \multicolumn{2}{|l|}{ Source: Results of EViews 10 software } \\
\hline
\end{tabular}

\section{Panel Data Regression Model Selection Chow Test}

Table 4. Chow Test
\begin{tabular}{|l|l|l|}
\hline Effects Test & Statistic & Probability \\
\hline Cross-section F & 2,958945 & 0,0174 \\
\hline Cross-section Chi-square & 33,410382 & 0,0002 \\
\hline \multicolumn{2}{|c|}{ Source: Results of EViews 10 software }
\end{tabular}

Based on the table above shows that prob. 0.0002 is less than 0.05 , so that the Fixed Effect Model (FEM) is better than the Common Effect Model (CEM).

\section{Hausman Test}

\begin{tabular}{l} 
Table 5. Hausman Test \\
\begin{tabular}{|l|l|l|l|}
\hline Test Summary & $\begin{array}{l}\text { Chi-Sq. } \\
\text { Statistic }\end{array}$ & $\begin{array}{l}\text { Chi-Sq. } \\
\text { d.f. }\end{array}$ & Prob. \\
\hline Cross-section random & 10.034683 & 6 & 0.1232 \\
\hline
\end{tabular} \\
\hline
\end{tabular}

The table above shows that prob. $=$ 0.1232 is larger than 0.05 , then the model used is the Random Effect Model, which is better than the Fixed Effect Model (FEM).

The Langrange Multiplier (LM) test aims to see between the CEM or REM models. This test is required when the results of the Chow test are CEM, and the Hausman test is REM. In this study, the results of the Chow test are FEM, so there is no need for the LM test.

\section{Hypothesis Test \\ T-Test (Partial Test)}

\begin{tabular}{l} 
Table 6. T-Test \\
\begin{tabular}{|l|l|l|l|}
\hline Variables & Coefficient & t-Statistic & Probability \\
\hline Constanta & $-0,981318$ & $-1,585628$ & 0,123 \\
\hline X1 & $-0,248918$ & $-2,519387$ & 0,0171 \\
\hline X2 & $-129,6168$ & $-0,940339$ & 0,3543 \\
\hline X3 & $-0,330474$ & $-2,368852$ & 0,0243 \\
\hline X4 & 130,1334 & 0,944449 & 0,3522 \\
\hline X5 & 0,019122 & 0,873832 & 0,3889 \\
\hline X6 & 0,940831 & 1,023194 & 0,3141 \\
\hline
\end{tabular} \\
\hline
\end{tabular}

\section{Moderated Regression Analysis (MRA)}

Table 7 Moderating Test
\begin{tabular}{|l|l|l|l|}
\hline Variables & Coefficient & t-Statistic & Probability \\
\hline Constanta & $-1,557213$ & $-2,896584$ & 0,0074 \\
\hline $\mathrm{X} 1$ & $-0,007126$ & $-0,020819$ & 0,9835 \\
\hline $\mathrm{X} 2$ & $-1,796751$ & $-1,517483$ & 0,1408 \\
\hline $\mathrm{X} 3$ & 2,140700 & 2,224140 & 0,0347 \\
\hline $\mathrm{X} 4$ & $-1,796751$ & $-1,517483$ & 0,1408 \\
\hline $\mathrm{X} 5$ & $-0,144946$ & $-1,571589$ & 0,1277 \\
\hline $\mathrm{X} 6$ & 2,920174 & 0,530291 & 0,6002 \\
\hline $\mathrm{X} 1 * \mathrm{Z}$ & $-0,005306$ & $-0,414832$ & 0,6815 \\
\hline $\mathrm{X} 2 * \mathrm{Z}$ & 0,100508 & 2,212039 & 0,0356 \\
\hline $\mathrm{X} 3 * \mathrm{Z}$ & $-0,081927$ & $-2,551107$ & 0,0167 \\
\hline $\mathrm{X} 4 * \mathrm{Z}$ & 0,100508 & 2,212039 & 0,0356 \\
\hline $\mathrm{X} 5 * \mathrm{Z}$ & 0,006516 & 1,807742 & 0,0818 \\
\hline $\mathrm{X} 6 * \mathrm{Z}$ & $-0,082899$ & $-0,429938$ & 0,6707 \\
\hline
\end{tabular}

\section{CONCLUSION}

Based on the results of data analysis and research discussion, the following conclusions can be drawn:

1. Based on the analysis of the liquidity variable, which is proxied using the current ratio, it has a significant negative effect on dividend policy.

2. Based on the analysis of profitability variables that are proxied using a negative return on assets, it is not significant to dividend policy.

3. Based on the analysis of the leverage variable, which is proxied using the debt 
to equity ratio, it has a significant negative effect on dividend policy.

4. Based on the analysis of activity variables proxied using total asset turnover, there is no significant positive towards dividend policy.

5. Based on the analysis of the positive growth variable, it is not significant to dividend policy.

6. Based on the analysis of the positive sales growth variable, it is not significant to dividend policy.

7. The Moderated Regression Analyst test shows that negative firm size does not significantly moderate the liquidity relationship, proxied using the current ratio to dividend policy, which is proxied using the dividend payout ratio.

8. The Moderated Regression Analyst test shows that the positive firm size significantly moderates the profitability relationship as proxied using return on assets to dividend policy as proxied using the dividend payout ratio.

9. The Moderated Regression Analyst test shows that negative firm size moderates the leverage relationship as proxied using the debt to equity ratio to dividend policy proxied using the dividend payout ratio.

10. The Moderated Regression Analyst test shows that the positive firm size significantly moderates the activity relationship as proxied using total asset turnover to dividend policy, which is proxied using the dividend payout ratio.

11. The Moderated Regression Analyst test shows that positive firm size does not significantly moderate the relationship between growth and dividend policy, proxied using the dividend payout ratio.

12. The Moderated Regression Analyst test shows that negative firm size does not significantly moderate the relationship between sales growth and dividend policy, proxied using the dividend payout ratio.

\section{Research Limitations}

1. The research period is relatively short, namely four years, which causes a limited number of samples.

2. The data collection method is through financial reports published by the Indonesia Stock Exchange so that the data collected is still limited only to the results of IDX publications.

3. The research sample is only limited to companies in the automotive sub-sector so that they do not represent all companies listed on the Indonesian stock exchange.

\section{Suggestion}

Based on the conclusions and limitations that have been found, the researcher provides several suggestions, including:

1. The company's management is strongly advised to pay more attention to the distribution of dividends to shareholders. It aims to attract investors to invest in the company when the company is experiencing funding difficulties.

2. Investors who will invest their funds are advised to be more careful in analyzing and paying attention to its performance, not affected by a false increase in dividend payments.

Acknowledgement: None

\section{Conflict of Interest: None}

\section{Source of Funding: None}

\section{REFERENCES}

1. Ahmad, G.N., \& Wardani, V.K. (2014). The Effect of Fundamental Factors to Dividend Policy: Evidence in Indonesia Stock Exchange. International Journal of Business and Commerce.Vol. 4, No.2.

2. Amalia. (2013). Pengaruh Karakteristik Perusahaan Terhadap Corporate Social Responsibility Disclosure di Bursa Efek Indonesia. Media Riset Akuntansi. Vol. 3, No. 1. 
3. Andriani, M. (2016). The Influence of Profitability, Liquidity, Leverage, Activity, and Size of Dividend Policy. Jurnal Akuntansi: Universitas Muhammadiyah Yogyakarta.

4. Arilaha, M.A (2009). Pengaruh Free Cash Flow, Profitabilitas, Likuiditas, dan Leverage Terhadap Kebijakan Dividen. Journal of Finance and Banking. Vol 13, No. 1

5. Aurangzeb., \& Tasfoura, D. (2012). Earning Management and Dividend Policy: Evidence from Pakistani Textile Industry. International Journal of Academic Research in Business and Social Sciences. Vol. 2, No. 10.

6. Baker, H. K., \& Powell, G. (2005). Understanding Financial Management. A Practical Guide. Oxford: Blackwell Publishing.

7. Barton, S. L., et al. (1989). Empirical Test of Stakeholder Theory Predictions of Capital Structure. Financial Management Association International. Vol. 18, No. 1.

8. Darmayanti, N.K.D., \& Mustanda, I.K. (2016). Pengaruh Pertumbuhan Penjualan, Jaminan Aset, dan Ukuran Perusahaan Terhadap Kebijakan Dividen pada Sektor Industri Barang Konsumsi. E-Jurnal Manajemen Unud. Vol.5, No. 8

9. Dewi, D. M. (2008). Pengaruh Likuiditas, Leverage, Ukuran Perusahaan Terhadap Kebijakan Dividen Tunai Dengan Profitabilitas Sebagai Variabel Intervening, Jurnal Akuntansi. Fakultas Ekonomi dan Bisnis, Universitas Lambung Mangkurat, Vol. 23 No. 1.

10. Erlina. (2011). Metodologi Penelitian. Medan: USU Press.

11. Fahmi, I. (2015). Analisis Laporan Keuangan. Bandung: Alfabeta.

12. Fitriana, A., Dewi, A. C., \& Setiawan, D. (2018). Recent Developments in Dividend Policy: Evidence from Indonesia. Jurnal Keuangan dan Perbankan. Vol 22, No.1

13. Gupta, A.T. (2018). Pengaruh Financial Distress dan Kualitas Corporate Governance Pada Manajemen Laba. E-Jurnal Akuntansi. Vol. 23, No. 2. Bali: Universitas Udayana.

14. Hadiatmo, D. (2013). Analisis Faktor-faktor yang mempengaruhi Kebijakan Dividen Studi Empiris Perusahaan Manufaktur yang Listing di Bursa Efek Indonesia Periode 2008-2010. Jurnal Akuntansi. Vol. 2, No. 1.
15. Hani, S. (2015). Teknik Analisa Laporan Keuangan. Medan: UMSU PRESS

16. Jensen, M. C., \& Meckling, W. (1976). Theory of the firm: Managerial behavior, agency cost and ownership structure. Journal of Finance Economic 3:305- 360. di akses

dari https://www.nhh.no/for/courses/spring/eco4 20/jensenmeckling-76.pdf

17. Kautsar, A. (2014). Analisis Pengaruh Firm Size, DER, dan Sales Growth Terhadap Dividend Payout Ratio dengan ROE sebagai Variabel Intervening pada Perusahaan Non Keuangan yang Listed di BEI tahun 20092011. Jurnal Bisnis Strategi. Vol 23, No.2.

18. Kuswanta, T. (2016). Pengaruh Leverage, Profitabilitas, dan Ukuran Perusahaan Terhadap Kebijakan Dividen Pada Perusahaan yang Terdaftar di Indeks Kompas 100. Jurnal Ilmu Manajemen. Vol. 13, No. 2.

19. Lestari, K. F., Tanuatmodjo. H., \& Mayasari. (2016). Pengaruh Likuiditas dan Profitabilitas Terhadap Kebijakan Dividen. Jurnal of Business Management Education. Vol. 1, No. 2.

20. Lukman Syamsuddin. 2013. Manajemen Keuangan Perusahaan-Konsep Aplikasi dalam Perencanaan, Pengawasan dan Pengambilan Keputusan. Jakarta: PT. Rajagrafindo Persada.

21. Magdalena, G.D., \& Majerowska, E. (2018). Determinants of Corporate Dividend Policy in Polish Companies Listed on WSE. eFinance. Vol. 15, No. 3.

22. Mahdzan, N.S., Zaiudin, R., \& Shahri, N.K. (2016). Interindustry Dividend Policy Determinants in the Context of an Emerging Market.Economic Research-Ekonomska Istrazivanja.Vol. 29, No. 1.

23. Masril. (2017). Pengaruh Likuiditas, dan Size Terhadap Kebijakan Dividen Dengan Laba Bersih Sebagai Moderate Perusahaan Manufaktur di BEI 2011-2015. Jurnal Wira Ekonomi Mikroskil. Vol. 7, No. 2. Riau: STIE Mahaputra Riau.

24. Munawir, S. (2010). Analisis Laporan Keuangan Edisi Keempat. Cetakan Kelima Belas. Yogyakarta: Liberty.

25. Nugraheni, N.P., \& Mertha, M. (2019). Pengaruh Likuiditas dan Kepemilikan Institusional Terhadap Kebijakan Dividen Perusahaan Manufaktur. E-Jurnal Akuntansi. Vol 26, No. 1. Bali: Universitas Udayana. 
Taufiqurrahman et.al. The effect of financial performance and sales growth on dividend policy with firm size as moderating variable in automotive sub-sector manufacturing companies listed on the IDX in 2016-2019.

26. Nur, T. (2018). Pengaruh Profitabilitas dan Likuiditas Terhadap Kebijakan Dividen dengan Firm Size Sebagai Pemoderasi Pada Perusahaan Manufaktur Yang Terdaftar di Bursa Efek Indonesia Periode 2013-2017. Jurnal Akuntansi. Vol.21, No. 2. Jakarta: Institut Bisnis Nusantara.

27. Nursandari, M. (2015). Analisis Faktor yang Mempengaruhi Kebijakan Dividen Dengan Size (Ukuran Perusahaan) Sebagai Variabel Moderasi Pada Perusahaan Manufaktur Yang Terdaftar DI Bursa Efek Indonesia. Jurnal Akuntansi. Yogyakarta: Universitas Negeri Yogyakarta.

28. Permatasri, D.I. (2018). Pengaruh Likuiditas, Profitabilitas, Leverage, dan Growth Terhadap Kebijakan Dividen Dengan Ukuran Perusahaan Sebagai Variabel Moderating. Jurnal Akuntansi: Universitas Sumatera Utara.

29. Pramana, G.R.A., \& Sukartha, I.M. (2015). Analisis Faktor-Faktor yang Mempengaruhi Kebijakan Dividen di Bursa Efek Indonesia. E-Jurnal Akuntansi: Universitas Udayana, Vol.12, No 2.

30. Priyo, E.M. (2013). Analisis Pengaruh Return on Asset, Debt to Equity Ratio, Firm Size, Growth, dan Free Cash Flow Terhadap Dividend Payout Ratio, Semarang: Universitas Diponegoro.

31. Purba, M.I., Lorent. J., Angga. A., Chintya., \& Juli. (2020). Pengaruh Profitabilitas, Pertumbuhan Perusahaan, Kebijakan Hutang, dan Likuiditas Terhadap Kebijakan Dividen pada Perusahaan Manufaktur. Jurnal Akuntansi dan Keuangan. Vol. 7, No. 1.

32. Sartono, A. (2001). Manajemen Keuangan Teori dan Aplikasi. Yogyakarta: BPEF.
33. Sitanggang, J.P. 2014. Manajemen Keuangan Perusahaan Ed.2. Jakarta: Mitra Wacana Medis.

34. Sulaiman, H., \& Sumani (2016). Analisis Pengaruh Likuiditas, Leverage, Aktivitas, Profitabilitas, Dan Growth Terhadap Kebijakan Dividen Emiten Yang Terdaftar Pada Indeks Lq-45 Periode 2011-2013. Jurnal Manajemen. Vol 13, No. 2. Jakarta: Universitas Katolik Atmajaya.

35. Susanty, A.L., Siahaan, Y., Efendi., \& Supitiyani. (2017). Pengaruh Profitabilitas dan Rasio Aktivitas Terhadap Kebijakan Dividen pada PT. Bumi Serpong Damai Tbk. Jurnal Sultanist. Vol. 6, No.1.

36. Swastha, B., \& Handoko, H. (2011). Manajemen Pemasaran Analisis Perilaku Konsumen. Yogyakarta. BPFE.

37. Widiastari, P. A., \& Yasa, G. W. (2018). Pengaruh Profitabilitas, Free Cash Flow, dan Ukuran Perusahaan pada Nilai Perusahaan. E-Jurnal Akuntansi. Fakultas Ekonomi dan Bisnis: Universitas Udayana. Vol. 23, No. 2

38. Windi, N., \& Wendy, M. A. (2018). Improving Corporate Values Through the Size of Companies and Capital Structures, ICOBEST: Atlantis Press 225.

How to cite this article: Taufiqurrahman, Erlina, Fachrudin KA. The effect of financial performance and sales growth on dividend policy with firm size as moderating variable in automotive sub-sector manufacturing companies listed on the IDX in 2016-2019. International Journal of Research and Review. 2021; 8(7): 258-266. DOI: https://doi.org/10.52403/ijrr. 20210736 